\title{
EHMTI-0220. Cortical excitability in episodic cluster headache
}

\author{
G Cosentino*, B Fierro, S Brancato, P Paladino, R Baschi, S Talamanca, S Indovino, F Brighina \\ From 4th European Headache and Migraine Trust International Congress: EHMTIC 2014 \\ Copenhagen, Denmark. 18-21 September 2014
}

\section{Background}

Cluster headache $(\mathrm{CH})$ is a severe primary headache disorder, whose pathophysiological processes remain largely unknown. Along with central disinhibition of the trigeminal nociceptive system and hypothalamic impairment, a cortical involvement has been supposed.

\section{Aim}

To evaluate cortical excitability in episodic $\mathrm{CH}$ patients by using different paradigms of transcranial magnetic stimulation (TMS).

\section{Methods}

Twenty-five patients with episodic $\mathrm{CH}$ and thirteen healthy subjects underwent an experimental session where we evaluated, in both hemispheres, motor-cortical response to: 1) single-pulse TMS: i.e. motor threshold (MT); input-output (IO) curves and cortical silent period (CSP) and 2) paired-pulse TMS: i.e. intracortical facilitation (ICF) and short intracortical inhibition (SICI). Thirteen patients were evaluated outside bout, while the remaining twelve patients were inside bout at the time of recording.

\section{Results}

We showed increased ICF values in the hemisphere ipsilateral to the side of pain in patients evaluated both outside and inside bout. Differently, IO curves showed increased slope in both hemispheres in patients examined outside bout, but only in the hemisphere contralateral to the affected side in those evaluated during bout.

\section{Conclusions}

Our results show a condition of increased cortical excitability in episodic $\mathrm{CH}$ both outside and inside bout.

Department of Experimental Biomedicine and Clinical Neuroscience

(BioNeC), University of Palermo, Palermo, Italy
Interestingly, cortical excitability was greater in the hemisphere ipsilateral to the side of pain in patients outside bout, but decreased in patients inside bout possibly due to activation of compensatory inhibitory mechanisms of cortical excitability. Along with subcortical and peripheral mechanisms, changes in cortical excitability could also play an important role in the pathophysiology of $\mathrm{CH}$.

No conflict of interest.

Published: 18 September 2014

doi:10.1186/1129-2377-15-S1-E11

Cite this article as: Cosentino et al.: EHMTI-0220. Cortical excitability in episodic cluster headache. The Journal of Headache and Pain 201415 (Suppl 1):E11.
(C) 2014 Cosentino et al; licensee Springer. This is an Open Access article distributed under the terms of the Creative Commons Attribution License (http://creativecommons.org/licenses/by/2.0), which permits unrestricted use, distribution, and reproduction in any medium, provided the original work is properly cited.
Submit your manuscript to a SpringerOpen ${ }^{\circ}$ journal and benefit from:

- Convenient online submission

- Rigorous peer review

- Immediate publication on acceptance

- Open access: articles freely available online

- High visibility within the field

Retaining the copyright to your article

Submit your next manuscript at $>$ springeropen.com 